\title{
Retraction Note: Mst1 facilitates hyperglycemia-induced retinal pigmented epithelial cell apoptosis by evoking mitochondrial stress and activating the Smad2 signaling pathway
}

\author{
Bing Wei ${ }^{1} \cdot$ Min Wang ${ }^{1} \cdot$ Wei Hao ${ }^{1} \cdot$ Xiangdong $\mathrm{He}^{1}$
}

Accepted: 12 July 2021 / Published online: 25 August 2021

(c) Cell Stress Society International 2021

Retraction Note to: Cell Stress and Chaperones (2019)24:259-272

https://doi.org/10.1007/s12192-018-00963-z

The Editor-in-Chief has retracted this article (Wei et al. 2019) because of significant text overlap and similarity of figures with an article published earlier (Geng et al. 2020). It appears that parts of Fig. $5 \mathrm{f}$ are similar to Fig. $4 \mathrm{~h}$ in the earlier article. The Editor-in-Chief therefore no longer has confidence in the integrity of the data in this article.

The authors did not respond to any correspondence from the editor or publisher about this retraction.

\section{References}

Wei B, Wang M, Hao W et al (2019) Mst1 facilitates hyperglycemiainduced retinal pigmented epithelial cell apoptosis by evoking mitochondrial stress and activating the Smad2 signaling pathway. Cell Stress Chaperones 24:259-272. https://doi.org/10.1007/ s12192-018-00963-z

Geng C, Wei J, Wu C (2020) Yap-Hippo pathway regulates cerebral hypoxia-reoxygenation injury in neuroblastoma N2a cells via inhibiting ROCK1/F-actin/mitochondrial fission pathways. Acta Neurol Belg 120:879-892. https://doi.org/10.1007/ s13760-018-0944-6

Publisher's note Springer Nature remains neutral with regard to jurisdictional claims in published maps and institutional affiliations.

The original article can be found online at https://doi.org/10.1007/ s12192-018-00963-z.

Xiangdong $\mathrm{He}$

conquer2012@163.com

1 Department of Medicine, He University, No.66, Sishui

Street, Hunnan District, Shenyang City, Liaoning Province,

China 